\title{
Recria de Bovinos Nelore em Pastos de Brachiaria brizantha com Suplementação Protéica ou com Acesso a Banco de Proteína de Leucaena lecocephala. Desempenho Animal ${ }^{1}$
}

\author{
Marcelo Queiroz Manella ${ }^{2}$, Antônio João Lourenço ${ }^{3}$, Paulo Roberto Leme ${ }^{4}$
}

\begin{abstract}
RESUMO - Foi avaliado o desempenho de 192 bovinos Nelore recém desmamados em pastos de brachiaria exclusiva (Teste) ou suplementados durante a estação seca (Seca), o ano todo (Ano) ou com acesso a banco de leucaena (Banco), em delineamento de blocos casualisados com quatro repetições. O suplemento fornecido na seca continha 46,9\% de PB, $70 \%$ degradável no rúmen e o das águas 43,9\% PB, $60 \%$ degradável. No período das secas, os animais dos tratamentos Ano e Seca tiveram ganhos maiores que os dos tratamentos Banco e Teste $(0,534$ e 0,486 vs 0,277 e $0,201 \mathrm{~kg} / \mathrm{d}$, respectivamente). Nas águas os animais dos tratamentos Ano e Banco ganharam mais peso que os de Seca e Teste $(0,782$ e 0,741 vs 0,584 e $0,645 \mathrm{~kg} / \mathrm{d})$. O ganho de peso vivo por unidade de área apresentou as mesmas tendências que os ganhos médios diários. A suplementação com fontes protéicas pouco degradáveis nas águas e o banco mostraram-se alternativas eficientes a serem exploradas.
\end{abstract}

Palavras-chave: banco de proteína, gado de corte, proteína não degradável, pastejo, suplementação alimentar, ganho de peso vivo

\section{Post-weaning Nelore Cattle Grazing Brachiaria brizantha with Protein Supplement or Free Access to a Protein Bank of Leucaena leucocephala. Animal Performance}

\begin{abstract}
The performance of 192 weaned Nelore steers grazing on Brachiaria brizantha pastures (Teste), or supplemented during the dry season (Seca), all year around (Ano) or with free access to a leucaena bank (Banco), was evaluated in a random block design with four replications. The dry season supplement had $46.9 \% \mathrm{CP}, 70 \%$ rumen degradable, and the wet season supplement, $43.9 \% \mathrm{CP}$, $60 \%$ degradable. During the dry season, the animals of Ano and Seca showed higher gains than Banco and Teste (.534 and .486 vs .277 and $.201 \mathrm{~kg} / \mathrm{day}$, respectively). In the wet season animals on Ano and Bank had higher gains than Seca and Teste (.782 and $.741 v s .584$ and $.645 \mathrm{~kg} /$ day). The live weight gain per unit of area showed the same behavior of daily gain. Supplements with escape protein or access to a leucaena bank during the wet season showed an efficient alternative.
\end{abstract}

Key Words: average daily gain, beef cattle, escape protein, feed supplement, protein bank, grazing, wet season

\section{Introdução}

O Brasil conta com o segundo maior rebanho do mundo, estimado em 151 milhões de cabeças, com o abate de 29 milhões de cabeças bovinas, produzindo um montante de 6,67 milhões de toneladas de equivalente carcaça. Esta situação desafia a pecuária de corte a produzir, de forma eficiente, carne bovina de boa qualidade e a baixo preço, de modo a antecipar a idade de abate para 24 meses. Isto pode ser obtido com animais terminados a pasto, sem a necessidade de confinamento (Euclides et al., 1998).

A maior dificuldade para a produção de carne a pasto, em condições tropicais e subtropicais, é a ocorrência da estacionalidade de produção das plantas forrageiras. Isto reflete em oscilações na produtividade e na qualidade das forrageiras durante $o$ ano.
Com isto há a necessidade de usar estratégias como a suplementação alimentar com concentrados energético-protéicos, ou através da associação de pastagens com leguminosas. Desta forma, é possível eliminar as fases negativas do crescimento, reduzindo a idade de abate e diminuindo o custo fixo, além de possibilitar aumento no giro de capital .

A suplementação protéica de animais em pastejo é uma ferramenta que permite corrigir dietas desequilibradas, melhorando a conversão alimentar e os ganhos de peso vivo e, por consequiência, diminuindo os ciclos da pecuária de corte (Peruchena, 1999). Segundo Poppi \& Mclennan (1995), para o acréscimo de 300 g no ganho de peso diário de animais com 200 $\mathrm{kg}$ de peso vivo, no período de verão, necessitar-seiam de cerca de $150 \mathrm{~g}$ de proteína adicional chegando ao intestino. Esta proteína pode ser proveniente da

\footnotetext{
1 Parte da dissertação de mestrado do primeiro autor. Trabalho financiado pela Fapesp.

2 Bolsista da Fapesp. E.mail: manella@esalq.usp.br

3 PQC IV do Instituto de Zootecnia, Nova Odessa, SP. E.mail: ajlourenco@izsp.br

4 Professor Doutor da FZEA-USP, Pirassununga, SP. E.mail: prleme@usp.br
} 
leguminosa, suplemento protéico ou ainda de fontes energéticas que melhorem a síntese de proteína microbiana.

As leguminosas possuem grande potencial para aumentar a produção animal nos trópicos, por serem boas fontes de proteína e nitrogênio solúvel, bem como de minerais. Dentre as leguminosas, a Leucaena leucocephala é uma das espécies de maior importância pelo seu potencial produtivo em termos qualitativos e quantitativos. Lourenço \& Carriel (1997) observaram ganho de 412 g/dia em animais pastejando $B$. brizantha $+L$. leucocephala na forma de banco de proteína, sendo superior aos ganhos de brachiária exclusiva, $337 \mathrm{~g} /$ dia. A utilização da leucena na forma de banco de proteína pode contribuir para melhorar ganhos diários por animal e por unidade de área.

Os objetivos do trabalho foram avaliar o desempenho de bovinos nelore a pasto, recebendo suplementação alimentar protéica ou com livre acesso ao banco de proteína de Leucaena leucocephala.

\section{Material e Métodos}

O trabalho foi realizado na Estação Experimental Central do Instituto de Zootecnia, localizado no município de Nova Odessa, SP. A área experimental utilizada era formada por 48 piquetes de um hectare cada, formando 16 parcelas experimentais, divididas em três piquetes. O pastejo foi rotacionado, com período de descanso e ocupação sendo de 42 e 21 , respectivamente. $\mathrm{O}$ delineamento experimental foi de blocos casualizados, com quatro tratamentos e quatro repetições.

Os tratamentos testados foram: (Teste) Pastagem exclusiva de Brachiaria brizanta, (Banco) Pastagem de Brachiaria brizantha associada a uma área adjacente (banco de proteína) com livre acesso a Leucaena leucocephala, (Seca) Pastagem de Brachiaria brizanta + suplementação alimentar fornecida no cocho na estação da "seca" (junho a novembro de 1998), (Ano) Pastagem de Brachiaria brizantha + suplementação alimentar fornecida no cocho durante o ano todo, tanto na estação da seca como na das águas (junho 1998 a maio de 1999).

O período da seca considerado durou 140 dias (25 de junho de 1998 a 12 de novembro 1999) e as águas de 174 dias ( 12 de novembro de 1998 a 4 de maio de 1999), sendo o período experimental total de 314 dias. A precipitação total e a temperatura mínima e máxima durante a realização do ensaio na estação seca e nas águas foram de 303,8, 13,3 , 26,6 e 1273,6 mm, 17,4 (min.) e $29,7^{\circ} \mathrm{C}$ (max.), respectivamente (Figura 1).

A pastagem utilizada era de Brachiaria brizantha cv. Marandu, e o banco de proteína de Leucaena leucocephala $\mathrm{cv}$. Cunnigaham representava $25 \%$ da área do piquete, ambos formados em 1990.

O solo do local é classificado como Latossolo Vermelho-Escuro-Orto com topografia quase plana e de boa drenagem. A análise química do solo apresentou as seguintes características em 1997: M.O.= $26 \mathrm{~g} / \mathrm{dm}^{3} ; \mathrm{P}=5 \mathrm{mg} / \mathrm{dm}^{3} ; \mathrm{K}=1,1 \mathrm{mmol} / \mathrm{dm}^{3} ; \mathrm{Ca}=$ $5 \mathrm{mmol} / \mathrm{dm}^{3} ; \mathrm{Mg}=2 \mathrm{mmol} / \mathrm{dm}^{3} ; \mathrm{H}+\mathrm{Al}=82 ; \mathrm{pH}$ $\left(\mathrm{CaCl}_{2}\right)=4,1 ; \mathrm{S}=8 ; \mathrm{T}=89,5 ; \mathrm{V} \%=8,6$.

Foi realizada adubação de manutenção na gramínea com $100 \mathrm{~kg} \mathrm{P}_{2} \mathrm{O}_{5} / \mathrm{ha}$, e $60 \mathrm{~kg} \mathrm{~K} / 2$ /ha, em maio de 1997, e por cobertura e a lanço de $100 \mathrm{~kg} \mathrm{~N} / \mathrm{ha}$ (500 kg de sulfato de amônio/ ha), em abril de 1998 e março de 1999.

A disponibilidade de forragem foi estimada pelo método do quadrado (1,0 m x 1,0 m), e a avaliação das áreas de Leucaena leucocephala foi feita segundo Lourenço et al. (1981), em cinco pontos aleatórios das áreas avaliadas. Foram determinadas a matéria seca a $105^{\circ} \mathrm{C}$, proteína bruta (PB) pelo método micro Keejdahl (AOAC, 1990), digestibilidade in vitro (Tilley \& Terry, 1963), fibra detergente neutro (FDN) e fibra detergente ácido (FDA; Robertson \& Van Soest, 1981).

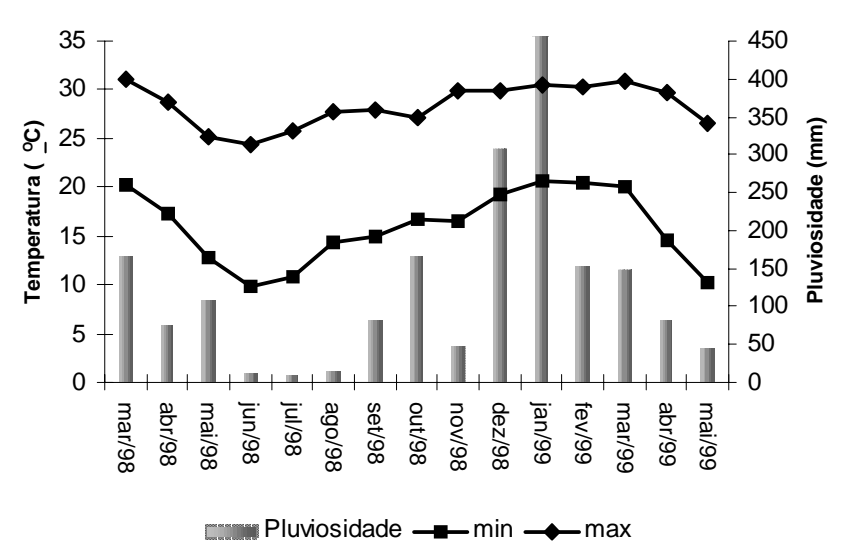

Figura 1 - Valores de temperatura $\left({ }^{\circ} \mathrm{C}\right.$, mínima e máxima) e pluviosidade $(\mathrm{mm})$ observadas durante 0 período experimental (junho de 1998 a maio de 1999).

Figure 1 - Temperature $\left({ }^{\circ} \mathrm{C}\right.$, minimun and maximun) and pluviosity $(\mathrm{mm})$ observed during the experimental period (June 1998 to May 1999).

R. Bras. Zootec., v.31, n.6, p.2274-2282, 2002 
Foram utilizados 192 bovinos machos inteiros da raça Nelore recém- desmamados, pesando em média $152 \mathrm{~kg}$ de peso vivo, para avaliação do desempenho animal. Os animais foram divididos em lotes e identificados com brincos numerados, sendo distribuídos para as respectivas parcelas, para o período de uma semana de adaptação. As medidas preventivas para controle sanitário foram tomadas de acordo com as recomendações técnicas para o rebanho.

O número de animais no período da seca foi de 12 animais por parcela, com carga animal média de 683 $\mathrm{kg}$ peso vivo/ha. Nas águas a carga animal média foi de $1182 \mathrm{~kg}$ de peso vivo/ha, sendo que ao início do período (novembro) foi necessária a adição de mais dois animais por parcela, sendo os mesmos retirados novamente em fevereiro devido ao acréscimo de peso dos animais. A carga animal foi ajustada para que, ao final de cada período de pastejo, o piquete apresentasse o mínimo de $1500 \mathrm{~kg}$ de MS/ha. As pesagens individuais dos animais foram feitas com auxílio de balança eletrônica em intervalos de 28 dias, sempre pelo período da manhã sem jejum.

Constam na Tabela 1 os ingredientes utilizados na composição do suplemento alimentar para os períodos das secas e águas e na Tabela 2, a composição química dos suplementos. Utilizaram-se 6,8\% de sal e $0,16 \%$ de Rumensin ${ }^{\circledR}$ (monensina) no suplemento para limitar oconsumoem aproximadamente $600 \mathrm{~g} / \mathrm{animal} / \mathrm{dia}$. O suplemento foi fornecido a cada três dias em cocho coberto, sendo que as quantidades eram ajustadas em função das sobras do concentrado do cocho.

Os resultados foram analisados através do programa computacional Statistical Analysis System (SAS, 1985), sendo anteriormente verificada a normalidade dos resíduos pelo teste de SHAPHIROWILK (PROC UNIVARIATE) e as variâncias comparadas pelo Teste $F$. Os dados que não atenderam a estas premissas foram submetidos à transformação $\operatorname{logarítima}[\log (X+1)]$ ou pela raiz quadrada $[R Q(X+1 / 2)]$. Os dados originais ou transformados, quando este último procedimento foi necessário, foram submetidos à análise de variância pelo procedimento GLM (PROC GLM) utilizando-se o comando REPEATED. As médias foram comparadas através do teste Tukey. Foi adotado um nível de significância de $5 \%$ para todos os testes realizados. Na presença de interação entre efeito do tratamento e de tempo, a separação foi feita dentro de cada período.
Tabela 1 - Suplemento para as estações da seca e das águas

Table 1 - Supplement composition of the dry and rainy seasons Ingrediente (\%) Estação seca $\quad$ Estação das águas Feedstuff Dry season Rainy season

$\begin{array}{lcc}\text { Farelo de soja } & 63,0 & 64,25\end{array}$

Soybean meal

Farelo de trigo

11,84

10,0

Wheat meal

Farinha de peixe

Fish meal

Uréia

Urea

Refinasil

Corn gluten feed

Caulim

Calcário

Limestone

Fosfato bicálcico

Dicalcium phosphate

Micro-nutrientes

Rumensin ${ }^{\circledR}$

Sal

Salt

Consumo/dia (g)

Feed intake/daily $(g)$

IPNDR/d $(\mathrm{g})^{1}$

RUDPI/d $(g)^{l}$

${ }^{1}$ Ingestão de proteína não degradada no rúmen.

1 Rumen undegradable protein intake.

Tabela 2 - Composição química do suplemento alimentar para o período das secas e das águas na base seca (\%MS)

Table 2 - Chemical composition of he supplement during the dry and rainy season (\%DM)

\begin{tabular}{lcc}
\hline $\begin{array}{l}\text { Composição química } \\
\text { Chemical composition }\end{array}$ & $\begin{array}{c}\text { Estação seca } \\
\text { Dry season }\end{array}$ & $\begin{array}{c}\text { Estação das águas } \\
\text { Rainy season }\end{array}$ \\
\hline MS $(D M)$ & 90,7 & 91,3 \\
NDT $(T D N)^{1}$ & 76,78 & 73,96 \\
PB $(C P)$ & 46,9 & 43,9 \\
PNDR $(R U D P)^{1,2}$ & 13,1 & 16,2 \\
FDN $(N D F)$ & 12,7 & 15,6 \\
FDA $(A D F)$ & 8,7 & 11,0 \\
MM $(A s h)$ & 20,3 & 17,7 \\
Ca & 3,2 & 1,7 \\
P & 1,2 & 0,6 \\
\hline
\end{tabular}

${ }^{1}$ Estimado pelo NRC (1996).

2 Proteína não degradada no rúmen (1996).

1 Estimated by NRC (1996)

2 Rumen undegradable protein (1996). 
O modelo estatístico utilizado foi:

$$
\mathrm{Y}_{\mathrm{ijk}}=\mathrm{m}+\mathrm{T}_{\mathrm{i}}+\mathrm{B}_{\mathrm{j}}+\mathrm{E}_{\mathrm{k}}+\left(\mathrm{T}^{*} \mathrm{E}\right)_{\mathrm{ik}}+\mathrm{e}_{\mathrm{ijk}}
$$

em que $\mathrm{Y}_{\mathrm{ijk}}=$ variável analisada; $\mathrm{m}=$ média geral; $\mathrm{T}=$ efeito do tratamento "i"; $\mathrm{B}_{\mathrm{j}}=$ efeito de bloco " $\mathrm{j}$ "; $\mathrm{E}_{\mathrm{k}}=$ efeito da estação do ano "k"; $\left(\mathrm{T}^{*} \mathrm{E}\right)_{\mathrm{ik}}=$ interação entre tratamento " $\mathrm{i}$ " e estação do ano " $\mathrm{k}$ "; $\mathrm{e}_{\mathrm{ijk}}=$ erro aleatório residual. As interações $\left(\mathrm{T}^{*} \mathrm{~B}\right)_{\mathrm{ij}} \mathrm{e}\left(\mathrm{T}^{*} \mathrm{~B} * \mathrm{E}\right)_{\mathrm{ijk}}$ também foram testadas; no entanto, por serem de menor magnitude, foram removidas do modelo estatístico final.

\section{Resultados e Discussão}

As avaliações de disponibilidade e composição química das pastagens de brachiaria e dos bancos leucena são mostradas na Tabela 3, para os períodos da seca e das águas.

Os pastos passaram por período de dois meses (abril e maio) de vedação antes do início do experimento, sendo que a temperatura e umidade (Figura 1), além da adubação feita em abril de 1998, favoreceram o crescimento e acúmulo de forragem. Desta forma, a disponibilidade média da brachiaria observada na Tabela 3 foi maior no período da seca quando comparada com o período das águas (4523 x $3921 \mathrm{~kg} \mathrm{MS} / \mathrm{ha})$. A gramínea na estação das águas apresentou valores de MS verde, PB e digestibilidade in vitro cerca de 29,7, 39,1 e 8,6\% superiores aos encontrados na época seca, como o esperado.
As características qualitativas (PB e digestibilidade) da leguminosa apresentaram valores praticamente constantes entre as duas épocas do ano para $\mathrm{PB}$ e digestibilidade, porém quantitativamente observou-se maior disponibilidade e relação folha/ caule terem sido superiores na estação das águas.

Os resultados de ganho diário de peso vivo para os tratamentos, no período das secas e das águas são apresentados na Tabela 4 e Figura 2. No período das secas, os tratamentos Seca e Ano obtiveram ganhos individuais médios diários superiores ao Banco e Teste (534 e $486 \times 277$ e $201 \mathrm{~g} / \mathrm{d}$, respectivamente), e no período das águas, os ganhos dos tratamentos Ano e Banco foram maiores que os animais Seca e Teste (782 e $741 \times 584$ e $645 \mathrm{~g} / \mathrm{d} ; \mathrm{P}<0,05)$.

Efeitos semelhantes da suplementação protéica no ganho médio diário no período das secas, ou quando as forragens apresentam qualidade inferior, foram observados em outros trabalhos (Njoya, 1997; Euclides et al., 1997; Ramos et al., 1998). Os ganhos médios de novilhos a pasto, suplementados na primeira estação seca, devem ser de 400 a $700 \mathrm{~g} / \mathrm{d}$, pois a melhora nos ganhos neste período terá repercussão no desempenho futuro dos animais (Peruchena, 1999). As médias de ganho (486 e 534 g/d) no presente trabalho estiveram de acordo com estas sugestões.

Paziani et al. (1998) forneceram suplemento protéico no período das secas para bovinos em pastos de brachiaria, com ganhos variando de $671 \mathrm{~g} / \mathrm{d}$ no

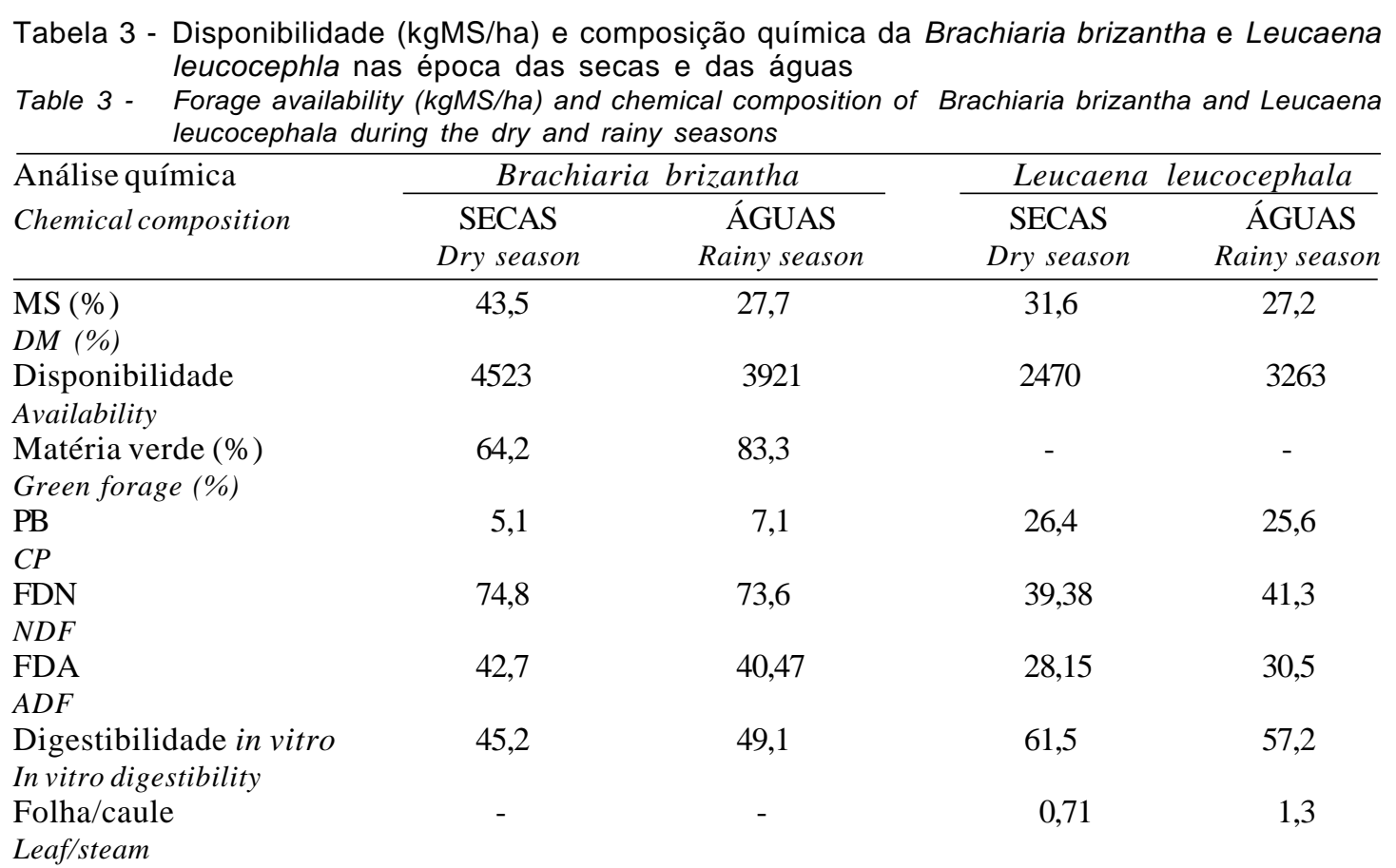

R. Bras. Zootec., v.31, n.6, p.2274-2282, 2002 


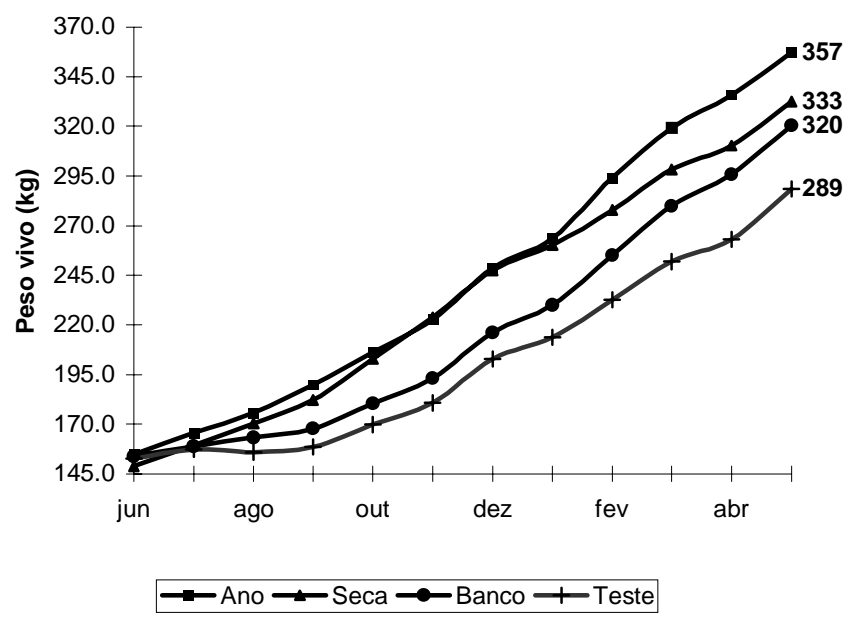

Figura 2 - Ganho de peso acumulado $(\mathrm{kg})$ de bovinos em Brachiaria brizantha (Teste), suplementados durante 0 ano todo (Ano), no período das secas (Seca), ou com livre acesso a banco de proteína de Leucaena leucocephala (Banco).

Figure 2 - Cumulative weight gain $(\mathrm{kg})$ of beef cattle during the dry, rainy season and annual of beef cattle grazing Brachiaria brizantha (Control), supplemented all year around (Year), on the dry season (Dry) or allowed to free accesses to protein bank of Leucaena leucocephala (Bank). início da suplementação, a 106 g/d ao final do período, sendo que nessa fase a baixa disponibilidade de forragem foi limitante, influindo para que ao final do experimento a média de ganho fosse de apenas $398 \mathrm{~g} / \mathrm{d}$, e o grupo controle com ganhos médios de $226 \mathrm{~g} / \mathrm{d}$. As médias foram inferiores às do presente trabalho no período das secas $(534 \mathrm{~g} / \mathrm{d}$ e $486 \mathrm{~g} / \mathrm{d}$ ) para os animais suplementados, sendo que a disponibilidade da forrageira $(4523,0 \mathrm{~kg}$ de MS/ha; Tabela 1) não foi limitante para o desempenho animal. Segundo Mancio et al. (1986), a suplementação protéica na estação seca só é eficiente quando a forragem disponível não for limitante.

Os efeitos da suplementação com concentrado protéico nos ganhos de peso vivo ocorreram em função da melhora no ambiente ruminal que, ao otimizar a utilização da proteína fornecida pelo suplemento, resultou em aumento da digestibilidade e ingestão de matéria seca da forragem e, conseqüentemente, na maior síntese e fluxo intestinal de proteína microbiana (Poppi \& McLennan, 1995; Olson et al., 1999).

A suplementação protéica no período das águas (grupo Ano) promoveu ganhos médios de $0,782 \mathrm{~kg} / \mathrm{d}$, sendo superior ao ganho obtido no período das secas

Tabela 4 - Ganho de peso médio(kg/d) durante o período das secas e águas de bovinos em Brachiaria brizantha (Teste), suplementados durante o ano todo (Ano), no período das secas (Seca), com livre acesso a banco de proteína de Leucaena leucocephala (Banco)

Table 4 - Average daily gain $(\mathrm{kg} / \mathrm{d})$ during the dry, wet season and annual of beef cattle grazing Brachiaria brizantha (Control), supplemented all year around (Year), on the dry season (Dry) or allowed to free acesses to protein bank of Leucaena leucocephala (Bank)

\begin{tabular}{|c|c|c|c|c|c|}
\hline \multirow[t]{2}{*}{$\begin{array}{l}\text { Peso vivo }(\mathrm{kg}) \\
\text { Live weight }(\mathrm{kg})\end{array}$} & \multicolumn{4}{|c|}{$\begin{array}{c}\text { Tratamento } \\
\text { Treatment }\end{array}$} & \multirow[b]{2}{*}{$\begin{array}{l}\text { Média } \\
\text { Mean }\end{array}$} \\
\hline & $\begin{array}{c}\text { Teste } \\
\text { Control }\end{array}$ & $\begin{array}{l}\text { Banco } \\
\text { Bank }\end{array}$ & $\begin{array}{c}\text { Seca } \\
\text { Dry }\end{array}$ & $\begin{array}{l}\text { Ano } \\
\text { Year }\end{array}$ & \\
\hline $\begin{array}{l}\text { Peso inicial na estação seca } \\
\text { Initial weight }\end{array}$ & 152,5 & 154,0 & 148,8 & 154,8 & 152,5 \\
\hline $\begin{array}{l}\text { Peso ao final das estação seca e início da estação das águas } \\
\text { Weight at end of dry season and beginning of wet season } \\
\text { Peso ao fim das águas }\end{array}$ & 180,8 & 193,0 & 223,8 & 222,8 & 205,1 \\
\hline Weigth at end of dry season & 288,5 & 320,3 & 332,5 & 357,3 & 324,7 \\
\hline $\begin{array}{l}\text { Ganho médio diário (kg/dia) } \\
\text { Average daily gain ( } \mathrm{kg} / \text { day) }\end{array}$ & $\begin{array}{l}\text { Teste } \\
\text { Control }\end{array}$ & $\begin{array}{c}\text { Banco } \\
\text { Bank }\end{array}$ & $\begin{array}{l}\text { Seca } \\
\text { Dry }\end{array}$ & $\begin{array}{l}\text { Ano } \\
\text { Year }\end{array}$ & $\begin{array}{l}\text { Média } \\
\text { Mean }\end{array}$ \\
\hline $\begin{array}{l}\text { Períodos } \\
\text { Periods } \\
\text { Estação da seca }{ }^{1}\end{array}$ & & & & & \\
\hline $\begin{array}{l}\text { Dry season } \\
\text { Estação das águas }{ }^{2}\end{array}$ & $0,201^{\mathrm{b}}$ & $0,277^{\mathrm{b}}$ & $0,534^{\mathrm{a}}$ & $0,486^{\mathrm{a}}$ & 0,375 \\
\hline $\begin{array}{l}\text { Rainy season } \\
\text { Média ponderada }{ }^{3}\end{array}$ & $0,645^{\mathrm{b}}$ & $0,741^{\mathrm{a}}$ & $0,584^{\mathrm{b}}$ & $0,782^{\mathrm{a}}$ & 0,688 \\
\hline Pondered mean & $0,447^{\mathrm{a}}$ & $0,534^{\mathrm{c}}$ & $0,562^{\mathrm{b}}$ & $0,649^{\mathrm{a}}$ & 0,548 \\
\hline
\end{tabular}

${ }_{a, b}$ Linhas com letras diferentes sobrescritas são significativas quando $P<0,05$.

ab Lines with different letters are significant at $P<.05$.

${ }^{1} \mathrm{CV}=39,43 ;{ }^{2} \mathrm{CV}=13,7 ;{ }^{3} \mathrm{CV}=37,7$.

Interação época do ano*tratamento: $P=0,0001$

Season of the year treatment interaction: $P=.001$.

\section{R. Bras. Zootec., v.31, n.6, p.2274-2282, 2002}


(0,486 kg/d). Outros autores (Poppi \& McLennan, 1995; Rossi, 1995; Mullik et al., 1998; Peruchena, 1999) também relataram ganhos expressivos quando fornecida uma suplementação protéica no período das águas.

A suplementação protéica de novilhos no verãooutono (Janeiro a Maio), em pastos de Brachiaria brizantha com farelo de algodão (0,6 \% PV), causou ganhos de $1140 \mathrm{~g} / \mathrm{d}$ e ao associar a energia os o desempenho foi de $1070 \mathrm{~g} / \mathrm{d}$, enquanto que os animais controle ganharam apenas $510 \mathrm{~g} / \mathrm{d}$. A suplementação permitiu terminar os animais com idade entre 20 e 22 meses, sendo que a dieta exclusivamente protéica promoveu menores custos que proteína-energia (Peruchena, 1999). Os resultados relativos às águas em nosso trabalho apresentaram tendências semelhantes às destes autores, porém com ganhos menores.

Rossi (1995), ao fornecer ração protéica ( $810 \mathrm{~g} / \mathrm{d}$, $41 \%$ PB) associando-se fontes degradáveis e não degradáveis a bovinos Zebu e cruzamentos com raças Européias no período das águas em pastos de Brachiaria brizantha, obteve ganhos médios de $1061 \mathrm{~g} / \mathrm{d}$ para os animais suplementados e $725 \mathrm{~g} / \mathrm{dia}$ para o grupo controle, ganhos superiores aos aqui relatados. Porém, naquele experimento, a média foi de 1,907, 0,779 e 0,498 g/dia para os períodos 1,2 e
3, respectivamente, desta forma devemos considerar possível ganho compensatório dos animais, já que a qualidade da forragem era equivalente em ambos os ensaios. No presente trabalho, o período de suplementação nas águas foi de seis meses e, conseqüentemente, os possíveis efeitos devido à maior taxa de ganho de peso diário ao início da estação das águas, foram diluídos.

Em razão de as gramíneas tropicais terem apresentado baixos valores de proteína e alta degradabilidade da mesma (All \& Stobbs, 1980; Malafaia et al., 1997), a suplementação nas águas com fontes protéicas de alta passagem para animais em pastagens tropicais resultou em ganhos mais elevados.

Segundo Poppi \& Mclennan (1995), existem poucas informações que acessem à informação do quanto a proteína é limitante no período das águas para forragens de climas tropicais, e que são pouco efetivas a suplementação protéica de animais pastejando forragens de alta qualidade. Todavia, ao lançar mão de suplementos com altas quantidades de proteína, podem-se obter respostas em ganho de 200 a 300 g/d. Nas águas, o consumo de proteína não degradável no rúmen estimado foi de $124 \mathrm{~g} / \mathrm{d}$, com ganhos de peso próximos dos ganhos propostos por Poppi \& Mclennan (1995) e Mbongo et al. (1994).

Tabela 5 - Ganho de peso vivo por hectare $(\mathrm{kg} / \mathrm{ha})$ durante o período das secas, águas e anual de bovinos em Brachiaria brizantha (Teste), suplementados durante o ano todo (Ano), no período das secas (Seca), ou com livre acesso a banco de proteína de Leucaena leucocephala (Banco)

Table 5 - Weight gain during per ha $(\mathrm{kg} / \mathrm{ha})$ during the dry, rainy season and annual of beef cattle grazing Brachiaria brizantha (Control), supplemented all year around (Year), on the dry season (Dry) or allowed to free acesses to protein bank of Leucaena leucocephala (Bank)

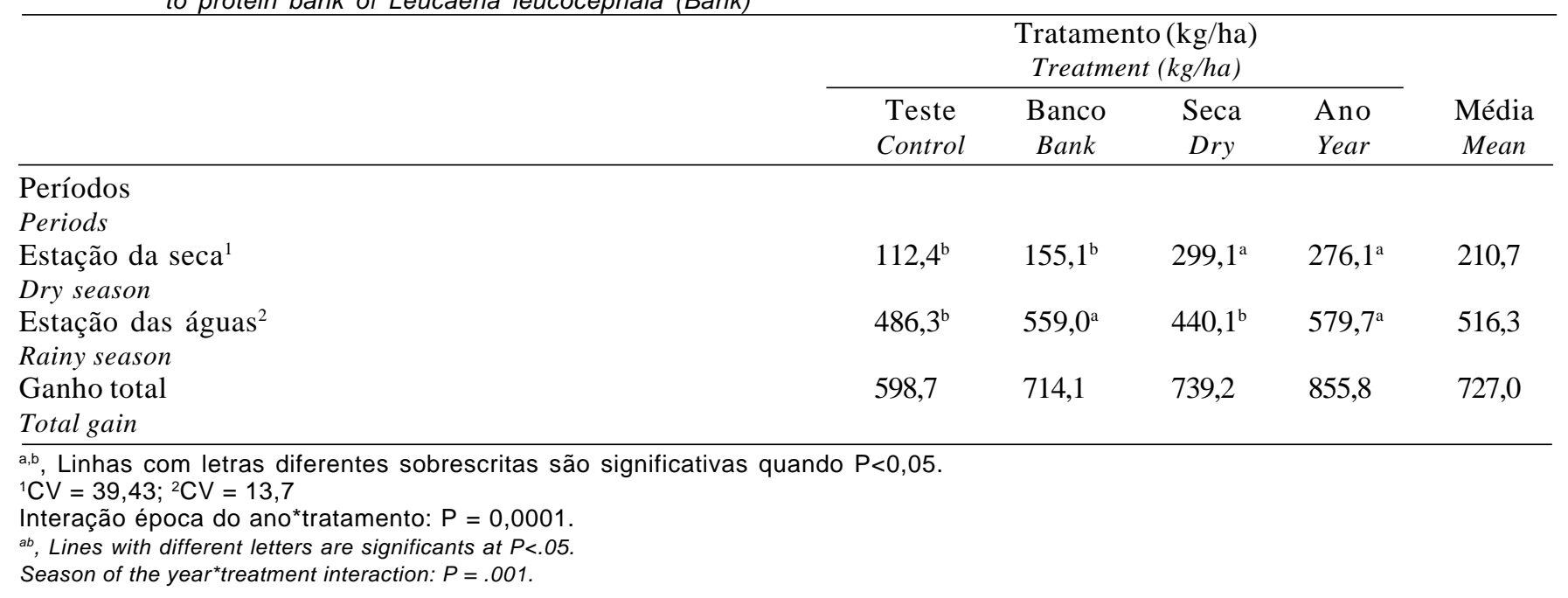

R. Bras. Zootec., v.31, n.6, p.2274-2282, 2002 
Os resultados aqui apresentados contradizem observações feitas por Mott et al. (1965), que avaliaram os efeitos de dois suplementos protéicos $(1 \mathrm{~kg} / \mathrm{dia}$ e $25 \%$ PB e $0,5 \mathrm{~kg} / \mathrm{dia}$ e $43 \%$ PB) e um energético ( $2 \mathrm{~kg}$ de melaço/dia) no desempenho de bovinos nelore na época seca e nas águas. As pastagens eram de capimcolonião adubados ou não com $100 \mathrm{~kg}$ de N/ha. Os teores médios de PB da forragem na estação da seca e nas águas foram de 5,5 e 7,5\% para pastagens não adubadas, e de 7,5 e $11 \%$ nos pastos adubados. Os efeitos da suplementação protéica foram maiores no período da seca nas pastagens não adubadas, porém as vantagens foram perdidas na estação subsequiente a das águas. A suplementação com melaço permitiu maiores ganhos individuais e por unidade de área tanto na seca como nas águas; provavelmente, devido ao melhor balanço proteína-energia.

A ausência de resultados satisfatórios da suplementação protéica no trabalho de Mott et al. (1965) pode ter ocorrido devido à maior quantidade de proteína na pastagem e à alta degradabilidade da mesma que, associadas ao suplemento, causaram desequilíbrio proteína-energia, prejudicando o desempenho animal devido ao maior gasto energético para excreção de uréia. Fato este não observado no presente trabalho, pois os níveis séricos de uréia para os animais suplementados foram em média 10,0 mg/dL (dados não apresentados), valores estes dentro do proposto por Hamond et al. (1993, 9,0-12,0 mg/dL), indicando o equilíbrio adequado na ingestão de proteína e energia.

A leucena apresentou ganhos satisfatórios apenas no período das águas (741 g/d), não diferindo estatisticamente do tratamento ano (Tabela 4). Lourenço \& Carriel (1998) também relataram maiores ganhos de animais em banco de leucena no período das águas, comparados aos da seca, sendo que as médias anuais mostradas nestes trabalhos foram de $464 \mathrm{~g} / \mathrm{d}$; neste ensaio, a média em todo período foi de $509 \mathrm{~g} / \mathrm{d}$.

Os maiores ganhos de peso do tratamento Banco nas águas (741 g/d), em relação ao grupo Seca (584 g/ d) e Teste $(645 \mathrm{~g} / \mathrm{d})$, ocorreram devido à maior oferta de MS da leguminosa e relação folha/caule mais elevada, possibilitando maior ingestão de proteína da leguminosa, sendo esta de baixa degradabilidade (All \& Stobbs, 1980; Franzolin Neto et al., 1992; Petty et al., 1998), porém de alta passagem, possibilitando maior fluxo de proteína verdadeira para o intestino delgado.

Os dados obtidos no presente trabalho são compatíveis aos observados por Lourenço \& Leme (1999). Em outro trabalho com os mesmos tratamentos, po- rém, os animais apresentavam idade mais avançada. As médias do ganho anual para os tratamentos Ano, Seca, Banco e Testemunha naquele trabalho (635, 469,502 e 396 g/d) apresentaram tendências semelhantes às apresentadas no presente trabalho (649, 562,534 e $447 \mathrm{~g} / \mathrm{d}$ ).

Quando realizadas análises estatísticas, o ganho por unidade de área apresentou o mesmo comportamento que os ganhos diários (Tabela 5). O ganho diário individual, bem como por unidade de área, e o peso final foram aumentados com a suplementação protéica quer na época das secas, ou quando suplementados durante o ano todo; sendo esta (em termos produtivos) a melhor alternativa.

O desempenho dos animais do banco de proteína durante o período das águas, assim como dos animais que estavam recebendo suplemento no mesmo período, mostrou maior capacidade de ganho, talvez por melhor relação energia-proteína (Poppi \& Mclennan, 1995).

Os animais do tratamento Banco apresentaram ganho compensatório parcial, pois ao final do período os animais apresentavam pesos próximos ao dos animais do tratamento Seca. Isto demonstra que o período das águas pode ser mais bem explorado pela suplementação alimentar protéico-energético, visando à melhor exploração do ganho compensatório dos animais. Por outro lado, os animais suplementados na seca, apesar de ganhos de peso numericamente inferiores aos animais do tratamento Teste, mantiveram as diferenças de peso ao final do período experimental. O peso final para os animais suplementados o ano todo, apenas na seca ou com acesso à leucena foram 2,4 1,7 e 1,1@ maiores que o ganho do tratamento testemunha, fato este que antecipará a idade de abate dos animais.

Ao calcular-se a eficiência alimentar $(\mathrm{kg}$ de ganho de PV/kg concentrado consumido), observaram-se valores de 2,66 e 1,0 para suplementação apenas na estação seca e no ano todo, respectivamente. Aparentemente, a primeira alternativa seria mais interessante no aspecto econômico. O maior peso obtido pelos animais suplementados (Ano e Seca) e pelo tratamento com acesso à leguminosa (Banco) permite a antecipação da idade de abate em relação ao Teste, possibilitando, desta forma, maior giro de capital e maior eficiência na produção de carne. De modo geral, os animais dos tratamentos Ano, Seca, e Banco tiveram ganhos médios durante o período experimental 45,1, 25,7 e 19,5\% maiores que o Teste.

\section{R. Bras. Zootec., v.31, n.6, p.2274-2282, 2002}




\section{Conclusões}

O ganho diário individual ou por unidade de área e o peso final foram aumentados com a suplementação protéica na época da seca, ou quando suplementados durante $\mathrm{o}$ ano todo; sendo este último, sobre o aspecto de ganho de peso diário, aparentemente a melhor alternativa. Porém, no aspecto econômico, a suplementação na seca é mais atrativa. Os resultados demonstram que a suplementação de animais a pasto pode ser feita de forma estratégica (secas e/ou águas) na fase de recria com consumo limitado de concentrado protéico (+/- $600 \mathrm{~g} / \mathrm{dia}$ e $+/-45 \%$ de PB), para incremento nos ganhos e antecipação da idade de abate.

Estudos com outras fontes alimentares de menor custo, bem como diferentes níveis de proteína e energia e suas respectivas interações para animais em pastagens tropicais, ainda necessitam de maiores esclarecimentos.

\section{Literatura Citada}

ASSOCIATION OF OFICIAL ANALIYTICAL CHEMISTS AOAC. Official methods of analyses. 15.ed. Washington D.C.: 1990. v.1. p.72-74.

AII, T.; STOBBS, STOBBS, T.H. Solubility of the protein of tropical pastures species and rate of its digestion in the rumen. Animal Feed Science and Technology, v.5, p.183-192, 1994.

ANUAlPEC 99. Anuário da Pecuária Brasileira. Ed. FNP Comércio \& consultoria, São Paulo. 1999. 447p.

EUCLIDES, V.P.B.; EUCLIDES FILHO, K.; ARRUDA, Z.J. et al. Desempenho de novilhos em pastagens de Brachiaria decumbens submetidos a diferentes regimes alimentares. Revista Brasileira de Zootecnia, v.27, n.2, p.246-254, 1998.

EUCLIDES, V.P.B.; EUCLIDES FILHO, K.; FIGUEIREDO, G. R. et al. Suplementação para produção de bovinos de corte. In: REUNIÃO ANUAL DA SOCIEDADE BRASILEIRA DE ZOOTECNIA, 34., 1997, Juiz de Fora, MG. Anais...Juiz de Fora: Sociedade Brasileira de Zootecnia, 1997. v.2, p.249.

FRANZOLIN NETO, R.; ANDRADE, P.; OCAMPOS, D. Degradabilidade da proteína e desdobramento da mimosina da Leucaena leucocephala (Lam) de with no rúmen de búfalos sob dietas com diferentes níveis de proteínas. Brazilian Journal of Veterinary Research and Animal Science, n.29, p.375-377, 1992.

HAMOND, A.C.; KUNKLE, W.E.; BATES, D.B. et al. Use of blood urea nitrogen concentration to predict response to protein or energy supplementation in grazing cattle. In: INTERNATIONAL GRASSLAND CONGRESS, 17. 1993, Nova Zelândia. Proceedings...Nova Zelândia: IGC, 1993. p. 189.

LOURENÇO, A.J.; MATSUI, E. Avaliação da proporção de gramínea e leguminosa na dieta de por determinação de isótopos estáveis de carbono nas fezes. Zootecnia, v.19, p.5-15, 1981.

R. Bras. Zootec., v.31, n.6, p.2274-2282, 2002
LOURENÇO, A.J.; CARRIEL, J.M. Desempenho de bovinos nelore em pastagens de Brachiaria brizantha associados a Leucaena leucocephala. In: REUNIÃO ANUAL DA SOCIEDADE BRASILEIRA DE ZOOTECNIA, 34., 1997, Juiz de Fora, MG. Anais...Juiz de Fora: Sociedade Brasileira de Zootecnia, 1997, v.2. p.345.

LOURENÇO, A.J.; CARRIEL, J.M. Desempenho de bovinos nelore em pastagens de Brachiaria brizantha associados a Leucaena leucocephala. Boletim da Indústria Animal, v.55, n.1, p.45-50, 1998.

LOURENÇO, A.J.; LEME, P.R. Desempenho animal em pastagens de Brachiaria brizantha associado a banco de proteína ou suplementação alimentar. In: REUNIÃO DA SOCIEDADE BRASILEIRA DEZOOTECNIA, 36., 1999. Porto Alegre, 1999. Anais... Sociedade Brasileira deZootecnia/Gmosis, [1999] 17par. CD-ROM. Forragicultura. Avaliação com animais. For-001.

LOURENÇO, A.J. Produção animal com leguminosas arbóreas/ arbustivas. In: SIMPÓSIO SOBRE USOS MÚLTIPLOS DE LEGUMINOSAS ARBUSTIVAS ARBÓREAS, 1993, Nova Odessa. Anais... Nova Odessa: Instituto de Zootecnia, 1993. p.131-146.

MALAFAIA, P.A.M.; VALADARES FILHO, S.C.; VIEIRA, R.A. et al. Determinação da cinética ruminal das frações protéicas de alguns alimentos para ruminantes. Revista Brasileira Zootecnia, v.26, n.6, p.1243-1251, 1997.

MANCIO, A.B.; VIANA, J.A.C.; AZEREDO, N.A. et al. Efeito da suplementação com semente de soja e uréia no período da seca sobre o potencial reprodutivo de fêmeas zebu. Arquivos da Escola de Veterinária, n.34, p.573-585, 1986.

MOTT, G.O.; QUINN, L.R.; BISSCHOFF, W.V.A. Supplemental feeding of steers and nitrogen fertilization and their effect upon beef production from guinea grass pasture. In: CONGRESSO INTERNACIONAL DE PASTAGENS, 9., 1965, São Paulo. Anais... São Paulo: 1965. p.981-988.

MULLIK, M.L.; POPPI; D.P.; MCLENNEN, S.R. Increasing growth rates of cattle in the wet season using supplements of molasse/urea combined with various protein sources. Animal Production in Australia, n.22, p.314, 1998.

NATIONAL RESEARCH COUNCIL - NRC. Nutrient requirements of beef cattle. 7.ed. Washington, D.C.: National Academy Press, 1996. 242p.

NJOYA, A. Protein supplementation of grazing cattle in the semi arid zone of Cameroon. Tropical Animal Health Production, v.4, p.193-200, 1997.

OLSON, K.C.; COCHRAN, R.C.; JONES, T.J. et al. Effects of ruminal administration of degradable intake protein and starch on utilization of low quality warm season grass hay by beef steers. Journal of Animal Science, v.77, n.4, p.10161025, 1999.

PAZIANI, S.F.; ANDRADE, P.; ALCALDE, C.R. Efeito do suplemento no desempenho de bovinos em pastagens no período da seca. In: REUNIÃO DA SOCIEDADE BRASILEIRA DE ZOOTECNIA, 35., 1998, Botucatu. Anais...Botucatu: Sociedade Brasileira de Zootecnia, 1998. p.497-499.

PERUCHENA, C.A. Suplementación de bovinos para carne sobre pasturas tropicales, aspectos nutricionales, productivos y economicos. In: REUNIÃO DA SOCIEDADE BRASILEIRA DE ZOOTECNIA, 36., 1999, Porto Alegre. Anais...Porto Alegre: SBZ/Gmosis,[1999] 17par. CD-Rom. Palestras. 
PETTY, S.R.; POPPI, D.P.; TRIGLONE, T. Effect of maize supplementation, seasonal temperature and humidity on the liveweight gain of steers grazing irrigated Leucaena leucocephala/Digitariaerantha pastures in north-west Australia. Journal of Agriculture Science, n.130, p.95-105, 1998.

POPPI, D.P.; McLENNAN, S.R. 1995. Protein and energy utilization by ruminnts at pasture. Journal of Animal Science, v.73, n.1, p.278-290, 1995.

RAMOS, J.A.; MENDONZA M.; ARANDA, E. et al. Escape protein supplementation of growing steers grazing stargrass. Animal Feed Science and Technology, n.70, p.249-256, 1998

ROBERTSON, J.B.; Van SOEST, P. J. The detergent system of analysis and its application to human foods. In: JAMES, W.P.T.; THEANDER, O. (Eds.) The analysis of dietary fiber in food. New York: Marcel Dekker, 1981. p.123-158.
ROSSI, J.H. Suplementação protéica de bovinos em pastagens de Brachiaria brizantha (Hochst. ex A. Rich) Stapf. cv. Marandu. Jaboticabal: Universidade Estadual Paulista, 1995. 28p. Monografia (Graduação em Zootecnia) - Universidade Estadual Paulista, 1995.

STATISTICAL ANALYSIS SYSTEM. SAS User's guides: statistics. 5.ed. Cary: 1985.

TILLEY, J.M.A.; TERRY, R.A. Two-stage technique for the in vitro digestion of forage crop. Journal of British Grassland Society, n.18, p.104-111, 1963.

Recebido em: 26/10/01

Aceito em: 18/06/02 